\title{
PENGOLAHAN SAYUR BAYAM MENJADI ES KRIM DI KELURAHAN PURANGI KECAMATAN SENDANA KOTA PALOPO
}

\author{
Antong $^{1}$, Astrina Maharani ${ }^{2}$ \\ Sekolah Tinggi Ilmu Ekonomi Muhammadiyah Palopo \\ ${ }^{1} E_{\_}$Mail: antong.cib@gmail.com
}

\begin{abstract}
Abstrak: Tujuan program ini adalah mengolah sayur bayam menjadi es krim sekaligus membina petani sayur bayam agar lebih inovatif dan kreatif dalam memberikan nilai tambah hasil pertanian mereka yang melimpah sehingga lebih berdaya guna dan bernilai ekonomis.

Pembuatan es krim sebenarnya sederhana saja, yakni mencampurkan bahan-bahan dan kemudian mendinginkan. Es krim yang biasanya terdapat di pasaran biasanya terbuat atau berbahan dasar susu cair.Metode yang digunakan dalam program iniyakni dengan melakukan penyuluhan sekaligus pelatihan kepada masyarakat setempat tentang pengolahan sayur bayam menjadi sebuah produk yang lebih menarik dan berniali ekonomis yaitu es krim bayam.

Kegiatan ini dilakukan dengan dukungan dari pemerintah setempat serta mahasiswa STIE Muhammadiyah Palopo.Selain itu masyarakat Kelurahan Purangi khususnya para petani serta kelompok kelompok masyarakat sekitarnya diberdayakan dalam kegiatan ini. Hingga saat ini program pelatihan kepada msayakat mengenai pembuatan es krim bayam telah dilakukan, selain itu pengetahuan mengenai pemasaran dan perhitungan harga pokok juga diberikan kepada masyarakat. Monitoring terhadap kegiatan masih akan terus dilakukan sebagai rencana tahapan selanjutnya.
\end{abstract}

Kata kunci : Sayur Bayam, Es krim

\begin{abstract}
PENDAHULUAN
Es krim merupakan makanan yang sudah tidak asing lagi bagi masyarakat. Membayangkan es krim akan terbayang kelembutan dan kelezatan rasanya. Rasa yang manis, gurih,dingin dan lembut amat menggugah selera. Pembuatan es krim sebenarnya sederhana saja, yakni mencampurkan bahan-bahan dan kemudian mendinginkan. Es krim yang biasanya terdapat di pasaran biasanya terbuat atau berbahan dasar susu cair. Peran dari susu sebagai rasa khas dari es krim ini bisa digantikan oleh bayam. Bayam adalah tumbuhan yang ditanam untuk dikonsumsi daunnya. Kandungan daun bayam terdapat Zat besi yang cukup untuk memenuhi kebutuhan zat besi dalam tubuh kita, ada beberapa manfaat dari daun bayam yaituManfaat Bayam sebagai untuk Penglihatan, Kedua antioksidan lutein dan zeaxanthin yang sangat banyak di bayam dan
\end{abstract}

melindungi mata dari katarak dan usia degenerasi makula terkait.Manfaat Bayam bagi kankerFlavonoid - sebuah phytonutrisi dengan sifat anti-kanker berlimpah dalam bayam - telah ditunjukkan untuk memperlambat pembelahan sel dalam perut manusia dan sel-sel kanker kulit. Selain itu, bayam telah menunjukkan perlindungan yang signifikan terhadap terjadinya kanker prostat agresif.

Manfaat Bayam sebagai AntiinflamasiNeoxanthin dan violaxanthin dua antiinflamasi epoxyxanthophylls yang memainkan peran penting dalam regulasi peradangan dan hadir dalam jumlah yang tidak biasa dalam bayam.Manfaat Bayam sebagai AntioksidanVitamin C, vitamin E, beta-karoten, mangan, seng dan selenium hadir dalam bayam semua berfungsi sebagai antioksidan kuat yang memerangi terjadinya osteoporosis, aterosklerosis dan tekanan darah tinggi.Manfaat Bayam untuk 
Tekanan DarahDengan angiotensin menghambat I-converting enzyme, peptida dalam bayam telah terbukti efektif menurunkan tekanan darah.Manfaat Bayam sebagai untuk KekebalanSatu cangkir bayam mengandung lebih $337 \%$ dari RDA vitamin A yang tidak hanya melindungi dan memperkuat "entry point" ke dalam tubuh manusia, seperti membran mukosa, saluran pernapasan, saluran kemih dan usus, tetapi juga merupakan komponen kunci dari limfosit (atau sel darah putih) yang memerangi infeksi.

Menurut World Healthiest's Food Rating (Virdias, 2013) bayam merupakan sayuran yang super karena mengandung vitamin $\mathrm{K}, \mathrm{A}, \mathrm{C}, \mathrm{B} 2$, B6, dan Vitamin B1, E yang very good dan Folat yang Excellent.Tidak hanya vitamin namun kandungan mineral bayam seperti besi, megnesium, mangan, kalium, dan kalsium yang sangat excellent.Belum terhitung tingginya serat yang dapat mencegah kanker saluran pencernaan dan mencegah terjadinya sembelit juga bantu cegah batu empedu. Dan di bawah ini merupakan tabel Kandungan Nutrisi Bayam per 100gr:

Pada saat ini, tanaman bayam jarang sekali dikonsumsi oleh masyarakat. Karena banyak masyarakat tidak menyukai sayuran bayam ini. Oleh sebab itu anak muda sering mengalami permasalahan terhadap penglihatannya. Bayam merupakan sumber vitamin A yang sangat tinggi, yang berguna untuk menyehatkan mata. Sebuah terobosan baru dilakukan dengan menggunakan bayam sebagai bahan dasar es krim yang diharapkan dapat mengurangi angka penggunaan kacamata di kalangan remaja, dan menjadikannya sebagai produk makanan yang lezat dan bernilai gizi tinggi.

\section{METODE PELAKSANAAN}

\section{Persiapan dan Pembekalan}

Proses pelaksanaan program ini akan dilaksanakan beberapa tahap. Tahap pertama, yaitu mencari alat-alat yang akan digunakan untuk mengolah bahan dasar dalam pembuatan produk. Tahap kedua, mencari bahan baku utama dan bahan-bahan lain yang dibutuhkan. Dalam tahap ini, bahan baku yang akan dicari adalah sayuran bayam, gula putih, vanili, garam, susu segar, dan susu skim.

Bahan-bahan yang dibutuhkan mudah di dapatkan di pasar. Setelah semua sudah terkumpul, barulah melaksanakan tahap ketiga yakni pengolahan terhadap bahan dasar untuk dijadikan produk yang diharapkan. Tahap terakhir adalah melakukan pengemasan pada produk dengan kemasan cup yang sudah disediakan kemudiaan dilakukan pemasaran ke konsumen melalui tahapan pemasaran yang dilakukan sendiri oleh pengusul.

\section{Pelaksanaan}

Langkah-langkah yang dilakukan dalam proses produksi program ini adalah:

1. Alat dan bahan disiapkan terlebih dahulu, Sayuran bayam direbus selama 7 menit kemudian angkat.

2. Bayam yang sudah diangkat lalu diblender hingga halus.

3. Gula, susu kental manis, agar-agar, air es dan bayam yang sudah diblender dimixer selama 3-5 menit untuk dicampurkan menjadi satu.

4. Semua bahan yang sudah dimixer menjadi satu adonan disimpan didalam lemari es dengan suhu $0-4^{0} \mathrm{c}$.

5. Pemeraman merubah kemampuan 
pengocokan adonan menjadi sebaik tekstur es krim akhir.

6. Pemeraman membuat lemak dari protein susu menjadi kristal dan bahan penstabil menyerap air bebas sebagai air hidrasi .

7. Pembekuan adonan dengan lemak tak berkristal akan cenderung menghasilkan suatu pengocokan yang tidak terkontrol dalam freezer.

8. Protein susu dan penstabil protein membutuhkan beberapa jam untuk menyerap airsebagai hidrasi.

9. Adonan membutuhkan waktu untuk diperam 24 jam. Bila diperam hanya 2-4 jam, hasilnya tidak nyata.

10.Adonan yang telah diperam selama semalam diaduk kembali agar tekstur menjadi lembut dengan menggunakan Mixer kemudian dikemas dalam wadah cup yang telah diberi label.

11. Es krim Bayam siap untuk dikonsumsi dan dipasarkan.

\section{Rencana Keberlanjutan Program}

Dalam metode pelaksanaan pemasaran ini, akan dipromosikan produk trobosan Es krim Bayam dengan cara mengenalkan langsung kepada konsumen atau calon pembeli bahwa susu dan bayam sangat bermanfaat bagi tubuh karena susu mengandung banyak gizi dan protein. Bayam sendiri merupakan sayuran yang kaya akan vitamin A sehingga baik untuk kesehatan mata. Kemudian juga kami akan memberikan brosur kepada konsumen agar mereka tertarik dengan melihat gambar. Kemudian memberikan sampel Es krim buatan kami sehingga mereka dapat mengenal rasa dari produk ini. Untuk mencegah Es krim cepat meleleh, Es krim akan ditempatkan kedalam strefoam yang diisi dengan es batu dan garam kasar agar suhu Es krim tetap terjaga.

\section{HASIL DAN PEMBAHASAN}

Pelaksanaan KKN PPM seperti tujuan awal peneliti untuk memberdayakan masyarakat dalam rangka meningkatkan perekonomian mereka. Pergram ini merupakan salah satu bentuk pengabdian perguruan tinggi kepada masyarakat Selain dengan bantuan dan keikutsertaan mahasiswa, kerjasama dengan masyarakat dengan pihak mitra dilakukan dalam rangka kelancaran program ini.

Adapun hasil dan luaran yang di capai dalam program ini sampai sekarang antara lain :

1. Pembentukan kelompok-kelompok mahasiswa dalam rangka pelaksanaan program KKN PPM ini.Selain itu pembentukan kelompok $\quad-$ kelompok masyarakat yang akan dibina dalam rangka pelaksanaan program

2. Terlaksananya pelatihan kepada kelompok masyarakat setempat tentang pengolahan bayam menjadi sebuah produk es krim. Pelatihan kerja pembuatan es krim Bayam agar masyarakat, terkhususnya Ibu-ibu dapat membuat keterampilan dengan membuat suatu produk yang dapat dijadikan sebagai home Idustry. Pelatihan ini tidak hanya mengenai cara membuat es krim dari bayam namun juga mencakup pelatihan mengenai pemasaran dan perhitungan harga produksi.

3. Luaran program ini merupakan produk rumahan berupa es krim bayam. 
Program KKN PPM pembuatan es krim bayam ini dilaksanakan bersamaan dengan jadwal KKN PPM Perguruan Tinggi STIE Muhammadiyah Palopo. Meskipun kegiatan pelatihan langsung kepada masyarakat telah selesai, namun tindak lanjut masih tetap harus dilanjutkan. Rencana tahapan selanjutnya dapat berupa monitoring kepada kelompok masyarakat binaan untuk mengetahui keberlanjutan pelatihan yang telah diberikan. Hal yag diharapkan program ini dapat bermanfaat bagi mereka sehingga pelatihan yang dibuat dapat terus berlanjut supaya masyarakat binaan dapat memperoleh pendapatan yang membantu perekonomian mereka. Selain itu laporan hasil serta pertanggungjawaban atas kegiatan ini tentunya msih akan terus di lanjutkan.

SIMPULAN

Pelaksanaan Program KKN PPM menjadi agenda Rutin bagi setiap Perguruan Tinggi, hal ini merupakan wujud pengabdian civitas akademika kepada masyarakat. Pelaksanaan kegiatan ini dilakukan juga untuk memberikan kesempatan bagi mahasiswa agar bisa berbaur dan memberikan kontribusi di masyarakat. Kegiatan KKN PPM pembuatan es krim bayam ini adalah salah satu bentuk kegiatan yang diharapkan dapat memberikan manfaat bagi kelompok binaan khususnya dalam rangka pemberdayaan masyarakat dalam peningkatan perekonomian masyarakat. Melalui program ini tim serta kelompok mahasiswa memberikan pelatihan dan penyuluhan dalam rangka pengelolaan/ pembuatan bayam menjadi produk es krim. Terlaksananya program ini tentunya dengan bantuan dari pihak pemerintah setempat dan pergururan tinggi yang mendukung penuh. Mulai dari tahap persiapan hingga pelaksanaannya.

Saran yang di bisa diberikan yakni, diharapkan akan ada program-program selanjutnya dapat di kembangkan sesuatu yang tetap memberikan dampak positif bagi masyarakat atau yang langsung menyentuh ke masyarakat setempat khususnya untuk skim pengabdian. Dengan begitu fungsi Perguruan Tinggi bukan hanya sebagai akademik namun juga berguna dalam masyarakat. Selain itu pemerintah setempat dapat lebih memperhatikan peluang-peluang usaha yang bisa dilakukan dengan memberdayakan masyakakatnya.

\section{DAFTAR PUSTAKA}

Abeng, Tanri. 2015. BUMR: Badan Usaha Milik Rakyat. Lembaga Pelaku Ekonomi dan Keuangan Inklusif. Kompas Gramedia

Padaga. M, M. E. Sawitri. 2005. Es krim yang Sehat. Trubus grisarana.Surabaya

Priscilla, Ineke. 2011. Pengaruh Konsentrasi Bayam (Amaranthus blitum L) dan Konsentrasi agar terhadap Karakteristik Es krim Nabati. Malang

Virdias, Tia Rahmania, 2013, Life Good with Green: Kandungan Nutrisi Bayam, http://umow.blogspot.com 